\title{
Digital Marketing Study, Through Instagram Media Case Study of Private Universities in the Tangerang Region
}

\author{
Indra Gunawan ${ }^{1)}$ \\ Tjong Se Fung2) \\ Diana Silaswara ${ }^{3)}$ \\ Universitas Buddhi Dharma Tangerang, Indonesia, Banten
}

\begin{abstract}
The rapid development of technology makes a big change to every activity carried out both individuals and organizations. The speed of information is a necessity for every individual and organization. Universities as institutions engaged in education make changes in communication to the community. In implementing the tri dharma of tertiary institutions in each of their activities, the tertiary institution utilizes social media. One of the social media chosen is Instagram because it is loved by millennials. The use of Instagram as a medium of communication has an impact on increasingly creative tertiary institutions conducting information on each of their activities. With the use of social media, tertiary institutions can inform the public about their creativity so that it impacts on public confidence in their learning activities
\end{abstract}

Key word: Marketing, Digital Marketing 


\section{PRELIMINARY}

The disruptive era is a state where changes occur so rapidly due to technological developments that enter every human life. The disruptive era makes technology a tool that makes it easy for humans to do their jobs and makes changes in accelerating the completion of human tasks. According to Kasali (2017: 139) the term "disruption" first emerged in the context of business, investment and finance.

Changes also occur nowadays such as changes in buying behavior, changes in promotional behavior, changes in behavior and other changes. Changes that occur due to the use of technology that is so massive. The development of the internet makes the world has no boundaries of space and time in interacting in all aspects of human life. The era of the internet is able to connect one country to another without need to wait for time.

In responding to rapid changes in time, Innovation is a keyword that must be done by every institution in responding to changes in circumstances and behavior. All institutions that offer products to consumers in the form of goods and services competing to innovate in establishing communication with consumers. The innovations made reach all aspects of activities such as production, marketing finance and others. Thus the use of technology in every activity must be carried out with the aim of efficiency and effectiveness of the activities that it does.

University as an education industry is one of the parties who make changes in carrying out its activities. The use of technology from the aspect of learning in the presence of e-learning makes it easy for students to conduct learning wherever they are. Aspects of the application of technology in terms of student administration such as student registration cards, study result cards make it easy for them to be able to access data quickly. Not only in terms of administration and learning, the marketing aspects of University also have an impact due to rapid changes in technology.

Marketing is an important activity for the sustainability of institution, especially a private institution. The current marketing pattern is more advanced than the old marketing pattern. The use of information technology in college marketing activities is one of the keys to success in establishing prospective students. Thus the authors are interested in doing "Digital Marketing Study of Private Universities in the Tangerang Region".

\section{THEORETICAL BASIS \\ UNDERSTANDING OF MARKETING}

According to Kotler and Armstrong (2014: 27) states The process by which companies create value for customers and build strong customer relationships in order to capture value from customers in return. From the above definition it can be interpreted that, marketing is the process by which companies create value for customers and build strong relationships with customers, with the aim of capturing the value of the customer in return.

According to Kotler and Keller (2016: 27) state marketing is the activity, set of institutions, and processes for creating, communicating, delivering, and exchanging offerings that value for customers, clients, partners, and society at large. The statement explains that marketing is an activity, regulating institutions, and processes for creating, communicating, delivering, and exchanging offers that are of value to customers, clients, partners, and society at large. Furthermore Kotler and Keller (2016: 27), said that 
Marketing is a sociental proces by which individuals and groups obtain what they need and want through creating, offering, and freeing, and freely exchanging products and services of value with others. The definition explains that. Marketing is a social process where individuals and groups get what they need and want through creation, offering, and freering, and free to exchange products and services of value with others.

From definiitions above. It can be concluded that marketing is an activity of communicating some of the advantages and values produced by a company to prospective buyers to match their expectations.

\section{MARKETING MIX}

Kotler and Armstrong (2014: 76) define the marketing mix as follows, marketing mix is the set of tactical marketing tools that the firm blends to produce the response it wants in the target market. The definition states that. The marketing mix is Consumer Characteristics Cultural, social, personal, a set of tactical marketing tools in a company blending the two produces the desired response in the target market.

The marketing mix can be described as follows:

1. Product

Is a combination of goods and services the company offers two target markets.

2. Price

Is the number of customers to be paid to obtain a product.

3. Place

Is covering the company's products available to target customers.Promosi

4. Promotion

It refers to the activity of communicating the good of the product and persuading target customers.

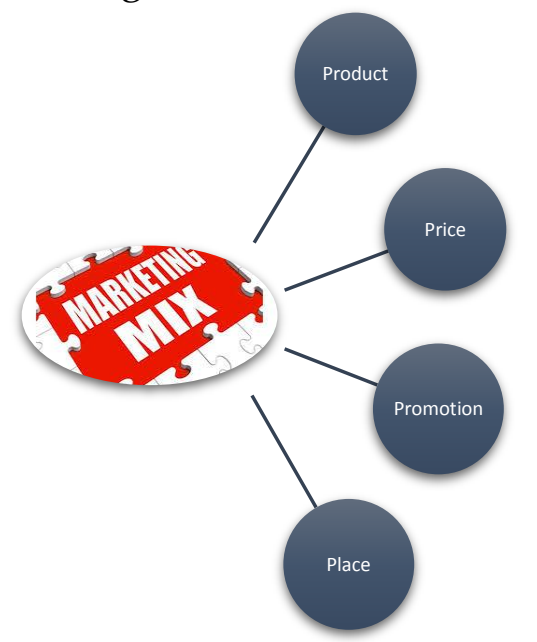

Sources: Kotler and Keller

\section{UNDERSTANDING DIGITAL MARKETING}

According to Gary, Wong, Philip Kotler, \& John Saunders, (2008) Marketing is managing customer relationships profitably. The dual purpose of marketing is to attract new customer by promising superior value and retaining current and growing customers by providing satisfaction.

E-Marketing or Digital Marketing according to Chaffey $\mathcal{E}$ Mayer, (2009) is marketing that has a broader scope because it refers to digital media such as the web, e-mail and 
wireless media, but also includes managing digital customer data, and also how the Internet can be used together with traditional media to obtain and provide services to customers.

From the explanation from the experts above, it can be concluded that digital marketing is a way for an organization to build a harmonious relationship with the use of information technology to establish closer relations with its customers.

\section{DIGITAL MARKETING OBJECTIVES}

According to Meyliana, (2011) in her journal entitled "Analysis of E-marketing Strategies and Their Implementation on Rental Companies" said e-marketing is part of e-commerce which is a trading system through the internet, where the internet will continue to provide the nature of up to date, then the company can provide product information services offered clearly and easily.Menurut Chaffey, Ellis-Chadwick, Mayer, Johnston, (2006: 9), e-marketing can be used to find several objectives such as:

- Identifying

The internet can be used as market research to find out the needs and desires of consumers.

- Anticipating

The internet provides additional channels that consumers can use to access information and make purchases.

- Satisfying

The key to success in e-marketing is achieving customer satisfaction through electronic channels, which raises questions such as: is the site easy to use, is its performance adequate, what are the related customer service standards and how are physical products delivered.

\section{DIMENSI PEMASARAN DIGITAL}

The dimensions of digital marketing according to Ryan (2012: 31) are

1. Website

Websites are the link between the digital world as a whole and an important part of marketing strategies.

2. Search Engine Optimization (Search Engine Optimization/SEO)

Is the process of managing content from websites to be easily found by internet users and can be easily found by search engines

3. Pay-per-click advertising Is a marketing tool that allows marketers to buy internet search results pages based on key words and sentences selected

4. Affiliate Marketing

Activities in partnership with other organizations / companies and websites to achieve mutual benefits from a partnership to promote products or services.

5. Online Public Relations

The use of online communication channels such as article syndicated press releases (RSS) and blogs to place an organization or company as an authority in a particular field

6. Social Network

The use of social networks such as Tweeter, Instagram, Facebook and etc is an effective media that connects an organization with its consumers.

7. E-mail Marketing 
The use of electronic mail replaces conventional media in the form of brochures and considered the most efficient way to apply.

8. Customer Relationship Management Building relationships with consumers with the use of telecommunications and information media is an effective means in order to reach comprehensive consumer.

\section{PREVIOUS RESEARCH}

In Theresia Pradiani's research entitled "THE EFFECT OF DIGITAL MARKETING MARKETING SYSTEM ON INCREASING VOLUME OF SALES OF HOME INDUSTRIAL RESULTS," Digital marketing is seen as the best media as the most effective and efficient means of promotion and able to increase sales volume significantly.

Other research that examines digital marketing was delivered by Bayu Bagas Hapsoro, Palupiningdyah Palupiningdyah, Achmad Slamet with the title THE ROLE OF DIGITAL MARKETING AS AN EFFORTS TO IMPROVE SALES OMSET FOR UMKM CLASTERS IN SEMARANG CITY. They stated that one of the indicators of increasing the welfare of MSME entrepreneurs was by increasing sales turnover. This condition is expected to be achieved, by maximizing digital marketing strategies, which is specifically designed for SMEs in the city of Semarang. This becomes important, because the acceleration of technology that moves very fast, causes changes in consumer behavior in selecting and buying and selling transactions. This situation drives MSMEs to be able to tidy up and innovate, not just to survive, but also to be able to enjoy the financial benefits of technological change that is occur.

Encep Sopandi in his journal entitled PROMOTION STRATEGY FOR RECEIVING NEW STUDENTS FOR PTS (A review of PTS Promotion activities in West Java in 2010) stated that in promotional activities there were elements of what was informed, the communication media used, and to whom the information was conveyed. In addition, there are also promotional activities to increase new students who are registered through the sales promotion approach.

Another research that discusses digital marketing was presented by Femi Oktaviani, and Diki Rustandi with the research title DIGITAL MARKETING IMPLEMENTATION IN BUILDING AWARENESS BRANDS. The results showed that digital marketing in building brand awareness was carried out by managing Instagram social media by carrying out activities in the form of advertisements, taglines, and carrying out marketing mix techniques such as personal selling, sales promotion and public relations in an effort to build brand awareness about Binong Jati knitting industry products.

Another research on digital marketing was conducted by Andrian SE, MM with the research title DIGITAL MARKETING AND PRODUCT VARIOUS IN SHOPEE ONLINE SHOPEE CONSUMER INTERESTS (CASE STUDY ON STUDENTS OF MANAGEMENT FACULTY OF ECONOMICS, BHAYANGKARA UNIVERSITY, JAKARTA RAYA, ARCHITECTURAL 2016 The results revealed that the digital marketing program and product variety had a significant influence on the buying interest variable.

From some of the previous studies above it can be concluded that the marketing program is an important activity for the survival of an organization. The dynamics of changing marketing patterns are faster in accordance with technological developments 
that have developed. Utilization of technology, especially in the field of marketing has become an inevitable part of all industries. Marketing activities that develop in this disruptive era have the key words, namely the development of creativity, building effective marketing patterns by using information technology in an effort to build better relationships with consumers so as to achieve the targets set by the organization.

\section{DISCUSSION}

Tangerang City is an area that borders directly with Jakarta. It has 13 districts with an area of 164.55 kilometers, making the city of Tangerang a city with a population of 2,185,304 people with a density of 13,280 people per kilometer. With its geographical position adjacent to the capital, the city of Tangerang is one of the destinations for economic activity, education and other infrastructure to support activities in the capital.

Proximity to Jakarta, making the city of Tangerang accelerate development as indicated by the Tangerang city development index figures. According to Wikipedia the Human Development Index (HDI) / Human Development Index (HDI) is a comparative measurement of life expectancy, literacy, education and living standards for all countries around the world. HDI is a tool to measure a country whether it is classified as a developed country, a developing country or an underdeveloped country and becomes a benchmark of economic policy on the quality of life of a country.

Tangerang City development index increases every year. This shows that the city of Tangerang has implemented policies to help people move towards a better direction. The graph of the development of the human development index can be seen as follows:

Indeks Pembangunan Manusia Kota Tangerang

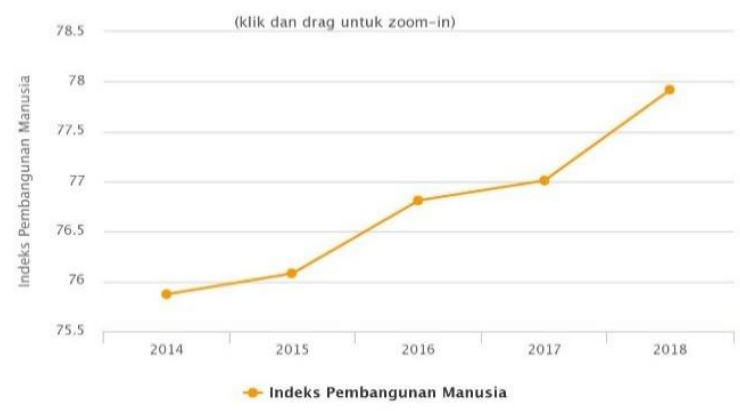

Source: BPS Kota Tangerang

The internet as a media that is highly loved by millennials today has a remarkable development in Indonesia. The development of internet users continues to grow from year to year. Survey of the Indonesian Internet Service Users Association (APJII) 2019 shows a development. With the development of the Indonesian economy which is still positively thought to make the purchasing power of Indonesian people feel better and able to buy and use information technology in every aspect of their lives. Data on the development of internet users can be seen as follows

\begin{tabular}{|ccrc|} 
Tahun & $\begin{array}{c}\text { Penduduk } \\
\text { (dlm Juta) }\end{array}$ & $\begin{array}{c}\text { Pengguna } \\
\text { Internet }\end{array}$ & $\%$ \\
\hline $\mathbf{2 0 1 8}$ & 266 & 143,26 & $54,68 \%$ \\
\hline $\mathbf{2 0 1 9}$ & 264,16 & 171,17 & $64,80 \%$ \\
\hline$\% \boldsymbol{\Delta}$ & $0,82 \%$ & $19,48 \%$ & \\
\hline
\end{tabular}

Sumber : Survey APJII 2019 
The data above shows that in 2019 internet users in Indonesia have reached $64.8 \%$ of Indonesia's population or grew by $10.24 \%$ in one year.

In addition, in terms of internet users based on age, they are still dominated by millennials. Data shows that the age of the most that use the internet is at the age of 1524 years. Data on internet penetration based on age can be seen as follows:

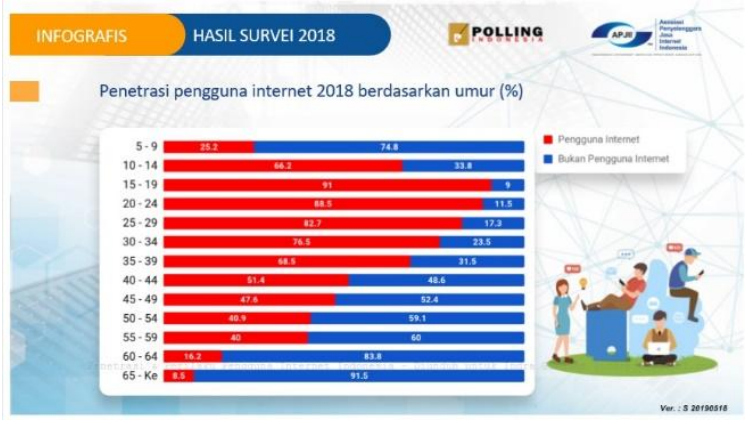

Source: APJII Survey 2019

From these two data it can be concluded that the development of the internet in Indonesia is dominated by millennials and has reached $64.8 \%$ of Indonesia's population. This figure represents a large market potential, given the total population of Indonesia which has reached 264 million. Thus the marketing channel in Indonesia can be said to be more effective if it is communicated with digital media.

University as an educational institution whose consumers are millennials also has a strategic interest in choosing media to communicate activities to the public digitally through social media. As an institution of University, of course bound by the rules made by the Ministry of Education, especially higher education of the Republic of Indonesia. Media such as Facebook, Instagram, are still effective media in binding activities to consumers. APJII survey shows that Facebook is still the main choice for internet users in social media, followed by Instagram and YouTube. The graphical info of the survey data is chosen as follows:

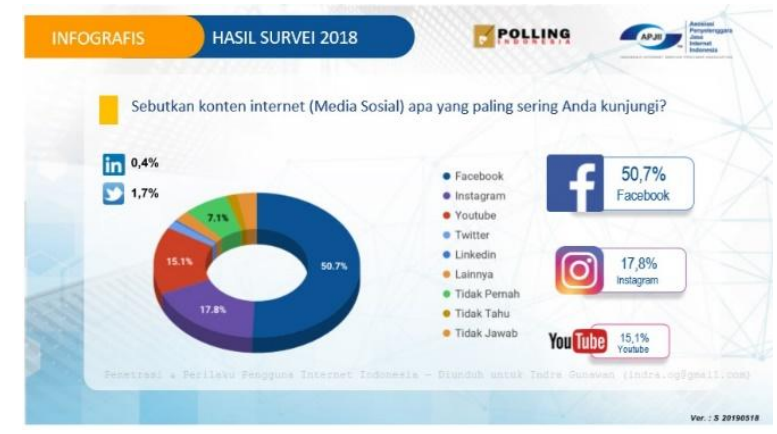

Sources : Survey APJII 2019

The phenomenon that is currently developing is that media such as Instagram and tweeters are still much loved by millennials in getting the information they want. Based on data released by the Redhills Asean Youth Survey 2019, it states that as many as $97 \%$ of Indonesian young people get online coverage through social media. From the existing social media channels, there are two platforms that are most trusted by the young generation of Indonesia namely Twitter and Instagram. In this article the author will examine a number of university activities in the Tangeerang area in communicating with stakeholders and prospective customers. This study 
examines the activities of social media, especially the activity of several universities in the city of Tangerang. Illustrations from the social media activities of several universities can be described as follows:

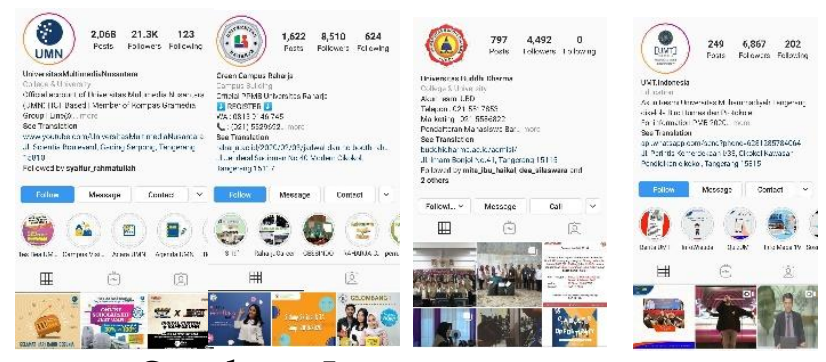

Sumber : Instagram

From these data it can be seen that the use of social media, especially Instagram, becomes a very effective communication media to reach consumers, evident from the average every college has social media.

\section{KONTEN}

In terms of content on social media, it can be seen that Instagram is the media to shape the college brand image. The average institution in the city of Tangerang is very varied in uploading on social media.

Forms of uploaded content are videos, pictures, Instagram TV photos, Instagram Stories and other forms. This media is an informative tool for campus activities carried out by all campus components ranging from lecturers, students and student activity unit activities (UKM). From the marketing side, this media college is much used to inform the activities of new student admissions. As we know, the reach of social media is large and it reaches internal and external marketing, so this media is much used by universities as marketing media.

In addition to the formation of institution branding, content made on Instagram is very varied and each college competes to make creative content to satisfy their audience. The use of applications or technologies such as animation is widely used so that the action of uploading content in institutions in the Tangerang area has a very large intensity with an average number of uploads above 1000 uploads.

The three aspects of higher education are also seen in every upload. Tridaharma institutions consist of research, teaching, and community service.

From the research aspect, every university always informs them in the form of news, photos of activities and releases made. Seminar activities, student programs, student work practices programs and others become content that is reported by universities.

Teaching activities also carried out the preaching. Many things are done by universities in campaign their activities to their followers. Examples of learning content are discussion and learning process activities carried out in class uploaded to show the community that universities are doing the learning process correctly that is supported by adequate facilities.

Student activities are also a lot of interesting content to be listened to because each university has different creativity in developing aspects of education for its students. 
Social activities are also a content that is widely uploaded by institutions in the Tangerang area. This shows that the activities in the institution refer to the three tridharma of higher education.

The digital age makes marketing patterns change dramatically. As stated by Kottler (2017: 52) that the era of digital marketing has changed to

- Aware,( Recognize the intended brand),

- Appeal,( stage of liking the brand)

- Ask, (Look for info about brands)

- Act,( Buying decision) and

- Advocate (Recommend a brand)

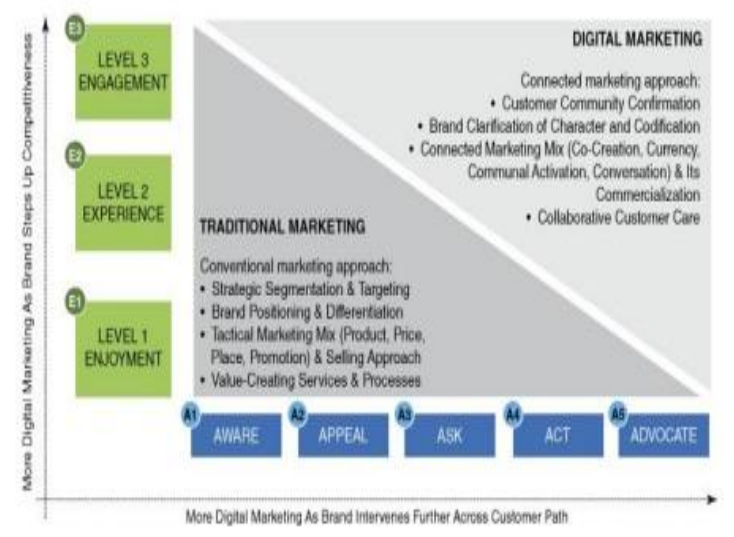

Sumber : Philip Kottler

Social media especially Instagram today is a media that is loved by millennials. Thus social media competition in the form of content enrichment is the main goal of every university in conducting campaigns to communicate and win the hearts of potential customers.

Market institution is divided into 2 namely internal market and external market.

For universities providing good experience to the internal market is the main goal to achieve WOM (word of the mouth) in other words internal marketing can voluntarily recommend to friends, relatives or relatives who want to go to college to join the college where they are studying.

For external marketing social media is a very efficient way for the Aware, Appeal, Ask, and Act processes, in determining the intended tertiary institution.

In marketing 4.0, Advocate can be done by giving satisfaction to the internals so activities carried out by universities will lead to a positive brand image and marketing activities.

\section{CONCLUSION} follows:

From some of the descriptions above, some conclusions can be drawn, as

- Rapid technological developments cause changes in every activity carried out both by individuals and organizations. 
- The use of information technology that is so massive causes organizations to change their communication strategies to consumers by using information media.

- Institutions as an education industry are aware of this technological change impacting on every activity $\square$ Tridharma of higher institutions is carried out by utilizing social media communication media, one of which is Instagram is much loved by millennials.Penggunaan insttitusi sebagai media komunikasi berdampak pada semakin creative universities in conducting information on every activity carried out.

\section{REFERENSI}

Chaffey, Dave; Mayer, Richard; Johnston, Kevin; Ellis-Chadwick, Fiona. (2006). Internet Marketing: Strategy, Implementation and Practice. Pearson Education Limited, United Kingdom.

Kasali Rhenald, Self-Disruption (2017) Jakarta: Gramedia Pustaka Utama,

Kotler, Philip, Kartajaya, Hermawan, and Setiawan Iwan, (2017) Marketing 4.0 Moving from Traditional to Digital, John Wiley \& Sons, Inc., Hoboken, New Jersey

Kotler, Philip dan Keller, Kevin Lane, (2016), Marketing Management, 14th Edition, Pearson Education Limited.

Kotler, Philip dan Amstrong, Gary, (2014), Principles of Marketing, 12th Edition, Jilid 1 Terjemahan Bob Sabran Jakarta: Erlangga.

Ryan, Damian \& Jones, Calvin. (2012). Understanding Digital Marketing: Marketing Strategies for Engaging The Digital Generation. United States: Kogan Page Limited

Sanjaya, Ridwan dan Josua Tarigan. (2009). Creative Digital Marketing. Jakarta: PT Elex Media Komputindo.

https:/ / lp2m.asia.ac.id/wp-content/uploads/2018/04/7.-JURNAL-THERESIA-

JIBEKA-VOL-11-NO-2-FEB-2017.pdf

https://journal.unnes.ac.id/nju/index.php/abdimas/article/view/17880

https:/ / ejournal.upi.edu/index.php/manajerial/article/download/1828/1246

https://ejournal.unitomo.ac.id/index.php/manajemen/article/view/1430

http://jurnal.unpad.ac.id/profesi-humas/article/view/15878

https://media.neliti.com/media/publications/167661-ID-analisa-strategi-emarketing-dan-impleme.pdf

https://id.wikipedia.org/wiki/Indeks_Pembangunan_Manusia

https:// www.wartaekonomi.co.id/read252785/2-media-sosial-ini-paling-dipercayamilenial-dan-gen-z-bisa-tebak 